\title{
From Farming to Development: Urban Coalitions in Pune, India
}

\author{
NEHA SAMI
}

\begin{abstract}
In an increasingly global India, an agricultural community in Pune, Maharashtra was faced with losing farmland to urbanization and devised an unusual solution. Pooling their land together, these farmers leveraged their social and political networks to take advantage of the changing economic climate in Pune and built a mixed-use township on their 400 acres of farmland. They formed alliances with other stakeholders, both internally within the agricultural community and externally at the city and state levels. This case study highlights the significance of ad-hoc coalitions in the power and politics of urban processes in an Indian city. These coalitions have emerged as a result of a political power and leadership vacuum in Indian cities in the face of the changing focus and priorities of national and regional governments as well as a growing gap in urban service provision.
\end{abstract}

\section{Introduction}

Few studies examining urban planning in India place issues of power squarely at the center of their arguments or focus on the role of specific actors in urban processes and the strategies that these actors employ. Moreover, research that does look at issues of power remains normative and does not focus on an understanding of the 'Realpolitik and real rationality that characterizes studies of power' (Flyvberg, 2002: 353). In particular, the study of Indian politics has been focused on examining the role of the nation-state (Kohli, 1986; Gupta, 1989; Kohli, 2004). While there have been studies on different aspects of urban India (Khilnani, 1999; Srinivas, 2001; Baviskar, 2003; Roy, 2003; Chatterjee, 2004; Heitzman, 2004; Nair, 2005), it is only recently that researchers have begun to take a look at contemporary actors involved in urban processes and the politics of these processes (Hansen, 2001; Roy, 2003; Benjamin, 2008; Weinstein, 2008). A particular area of interest has been the relationship between the government (at national, regional and local levels) and actors outside government, highlighting the role that informal networks play in urban development and governance processes. This study adds to that work by exploring how politics, social networks and the relationships between state and non-state actors influence and impact real estate development.

In the last two decades, urban India has undergone a transformation. A change in the focus and priorities of national and regional governments reflected especially in the gradual withdrawal of active government involvement in urban development, lack of

I would like to acknowledge the financial support provided for this work by a two-year studentship from the Foundation for Urban and Regional Studies (FURS), as well as fellowships from the Department of Urban and Regional Planning and the Rackham Graduate School at the University of Michigan. I would like to thank Gavin Shatkin for his input and patient reading of multiple drafts of this article, and the three IJURR referees for their very helpful comments. Any errors remain my own. 
political and administrative leadership and a growing gap in urban service provision have created a political power vacuum in Indian cities. The liberalization of the economy has also opened up avenues of interaction and participation that were earlier inaccessible. ${ }^{1}$ This has created the perfect situation for opportunistic urban stakeholders such as business leaders, politicians, bureaucrats, landowners, farmers and NGO leaders, from both 'corporate' and 'local' economies (Benjamin, 2000) to create 'participatory spaces' (Sridharan, 2008: 293) in which to act. ${ }^{2}$ Taking advantage of this political vacuum, urban stakeholders use their social and political networks to form ad-hoc coalitions that are often temporary, short-term in nature, with a particular goal in mind. Focusing on power and politics in urban processes, this article examines actors involved in mega-project development and the coalitions they formed in the city of Pune in the Indian state of Maharashtra.

Faced with losing their land and livelihood to urbanization, an agricultural community on the eastern edge of Pune leveraged their social and political networks and pooled their land together to convert 400 acres of farmland into an integrated, mixed-use township called Magarpatta City. Using this case as a lens, I examine the politics of urban development in Pune. I focus on how longstanding power structures and political networks are adapting to a changing political and economic urban environment. My main research question asks what role power structures and political networks play in urban development processes in India. Moreover, in the context of the commodification of land and the heating up of Indian real estate markets, how do these dynamics of power change?

Focusing on Pune, I find that the program of economic reform that began in the 1990s has provided actors who were earlier not directly involved in urban development with the opportunity to capitalize on assets like control over land and access to social and political connections. This has been enabled in part by state government incentives for new and emerging industries like information technology and biotechnology focusing explicitly on land development (Government of Maharashtra, 2007). I also show how these actors built coalitions and acted outside the 'formal' legal and institutional frameworks to successfully complete their development projects. While a wider variety of urban actors are now able to participate in urban development, my research found that, in the case of Pune, these actors are usually well connected socially and politically, and use these connections as a starting point for building coalitions.

\section{Theorizing urban politics in India}

Rapid growth in the Indian urban population (United Nations Population Fund, 2007) has been accompanied by demands for improved infrastructure, better governance and a growing need for land and real estate development. As a result, the Indian government

1 For example, economic reforms have made a wide variety of financial products such as personal home loans, small business loans and financing for real estate development more easily available, giving a boost to local real estate development. In addition, economic liberalization has encouraged the growth and development of new industries like information technology and biotechnology. This in turn has created a growing demand for new kinds of office space, as well as more housing and related development, which has also fueled real estate markets in Indian cities.

2 Benjamin (2000) defines 'local economies' as those that develop largely outside the master plan area, are often informal in nature and provide the majority of the urban (poor) population with employment and accommodation. 'Corporate economies', on the other hand, are the strongholds of the wealthier urban residents, including those working in newer industries like information technology. Benjamin specifically differentiates between local and corporate economies on the basis of their interactions with government: local economies interact with government through local-level officials while corporate economies usually have connections with higher-level government officials and politicians. 
has begun to encourage large-scale involvement of the private sector, domestic and international, in various aspects of urban development. Private sector participation has increased significantly in areas that were formerly under the purview of governmental agencies including infrastructure development and housing, particularly since 2005 when the Indian government started allowing foreign direct investment in real estate. The building of these development projects in the Indian context is accompanied both in physical design and rhetoric, by the aspiration to become 'global' or 'world-class', echoing the sentiments of city and state governments (Times News Network, 2006; PTI, 2009; The Hindu, 2010). This desire to achieve 'global city' status is also evident in emerging urban policy; prompting the creation of advisory bodies like urban taskforces (for example, the Bangalore Agenda Task Force set up by the Karnataka state government in the late $1990 \mathrm{~s}$, or the 'Bombay First' group that emerged as a recommendation of the Maharashtra government-commissioned McKinsey and Company's 'Vision Mumbai' report) and governments undertaking reforms to help Indian cities become 'global'. This section explores the Indian urban context and possible ways of theorizing Indian urban politics given the diverse array of stakeholders involved in processes of urban development.

The last two decades have seen the empowerment of several actors (for example, real estate developers, local entrepreneurial politicians, designers and planning consultants, civil society organizations), and the emergence of others who were almost entirely absent previously (like international architects and global financial companies) (Dupont, 2007; Jha and Sinha, 2007; Sharma and Thomson, 2010). While mutually beneficial political alliances are not unusual or indeed novel in Indian cities, the coalitions discussed here are different because several of their members would not have had the power or influence over urban development and policy issues prior to economic liberalization that they do now. Urban alliances or coalitions of the type examined in this study have their roots in personal social networks and are formed around the ability of various stakeholders to mobilize specific resources and use their personal relations as bargaining tools. These coalitions include a variety of stakeholders ranging from government bureaucrats and politicians to corporate leaders, urban planners and civil society organizations. As compared to the established governmental and quasi-governmental institutions that are currently charged with planning and governing Indian cities, alliances of this sort are infinitely adaptable in terms of the number and type of participants, how long the alliances exist and their purpose.

The coalitions are also flexible in the form they take — while some engage with specific issues relating to land and its development, others have a larger agenda of urban reform of which land-related issues are only one part. These urban coalitions have no institutional home and lie between the formal and the informal, the legal and the illegal. They are becoming more effective at achieving their goals than several governmentinitiated and executed urban development and governance efforts. However, this increase in efficiency is often accompanied by a trade-off in equity. Since these coalitions tend to have a narrow focus, aiming only to successfully achieve their goals, they do not address the needs of a broader urban population in the same way a government would. In order to understand contemporary urban development in India, it is necessary to understand how these urban coalitions emerge, endure, and often, succeed.

Most work on Indian politics either examines the working of the 'state' at a high level (Kohli, 1987; 1990; Kundu, 2003; Aijaz, 2008) or emphasizes grassroots mobilization and people's movements (Benjamin, 2000; Baviskar, 2003; Shaw, 2007). Other approaches have examined Indian politics from a subaltern perspective (most prominently, the work of Partha Chatterjee). However, these studies have left unexplained the details of how city government and the politics of development interact with and take advantage of higher-level changes that are key to understanding contemporary urbanization in India and beyond. This study takes a step in that direction by examining how specific actors in Indian cities mobilize to take advantage of current economic and political conditions to attain particular goals. While these questions have 
been undertheorized in Indian urban studies, other scholars working in a variety of other contexts have extensively discussed similar issues, particularly in applications of regime theory and the growth machine thesis (Stone, 1989; Kirby and Abu-Rass, 1999; Fainstein, 2001; Zhang, 2002; Wood, 2004; Dahl, 2005; Kulcsar and Domokos, 2005; Strom, 2007; Yang and Chang, 2007; Shatkin, 2008). Although regime theory has not been used explicitly in published work in the Indian context, there have been some studies in recent years that examine the dynamics of contemporary urban politics in India, focusing on specific political actors in Indian cities (for example, see Kamath, 2006; Weinstein, 2008; 2009; Ghertner, 2011). Frameworks used by the growth machine thesis and regime theory can therefore provide a useful, though somewhat unusual, starting point for understanding these changes in India.

Both regime theory and the growth machine thesis raise questions about urban development and governance that are very relevant to contemporary Indian urbanization. The growth machine thesis (Logan, 1976; Molotch, 1976; Logan and Molotch, 1987) focuses on urban land, its control, development and transfer, and on those actors concerned intimately with land. Drawing on studies of urbanization in the US, the growth machine thesis argues for a 'politics of place', raising questions not only about 'who governs' but also 'for what'. It claims that local politics revolves around land and its development; and that this politics is dominated by a pro-growth coalition of key urban actors, which ultimately shapes urban future through its transformation of local policy (Logan et al., 1999). Urban regime theory takes a broader approach, addressing issues of social power and the role that coalitions between interested parties play in the development and governing of cities, of which land is but one issue (Stone, 1989; Fainstein, 1995; Lauria, 1999). Regime theorists are interested in the question of who makes up the governing coalition, how they came together and with what consequences (Stone, 1989). It focuses largely on the relationship between those that wield economic power (usually large corporations) and those in government. Regime theory also situates cities within a larger global framework, acknowledging the impact that processes of globalization and worldwide economic restructuring have on the social order within cities (Fainstein, 1995). I explore the idea of coalitions and the notion of social power borrowed from the growth machine thesis and urban regime theory and their applicability in the Indian context. While these ideas provide a useful starting point to examine power structures and the role that stakeholders play in Indian cities, the conclusions that emerge from the Indian urban experience are distinct.

Growth coalitions as discussed in these theories are usually a result of a partnership between powerful local economic actors, represented by city businesses, and governmental authority in the form of an elected mayor. Both growth machine and regime theory assume considerable local agency on the part of the mayor as well as local businesses in mobilizing regimes around a specific shared development agenda. However, the case in India is somewhat different: although cities do have mayors, they are often toothless and lack the power to actually mobilize coalitions. City governments are also not as powerful in India, with state-level governmental actors like the Chief Minister, the state cabinet and various parastatal agencies exercising considerable power over urban development. Lacking formal political power and responsibility, local actors tap informal networks, leveraging their personal relationships with influential state-level actors. The coalitions that exist in Indian cities build on personal social networks, making individual relationships much more important. Coalition members in India are typically urban actors who share longstanding informal social relationships with each other. As opportunities arise, urban actors build on these informal relationships to create urban coalitions with specific goals in mind. These goals could vary from successfully accomplishing a real estate development project to changing the urban governance policy in the city.

Also, unlike in theories that argue for a single governing coalition or a growth machine, in Indian cities there may be multiple coalitions functioning at any particular point. In part, this is the outcome of a pluralist politics in India. Moreover, power in urban 
India is fragmented: there is no single interest group that controls enough resources (financial, political or governmental) to be the driving force in a single coalition. The nature of urban political power in India, therefore, almost requires numerous coalitions that reflect the various power groups in the city. There are several interest groups in Indian cities that wield significant influence and power, and this is reflected in the multiplicity of coalitions.

To begin to develop a theory of power in Indian urban politics, this study examines the role that coalitions play in urban development, how urban coalitions in India mobilize and function, what gives their members access to power and how government is responding to these changes. I find that urban coalitions in India are emerging as a response to an urban power vacuum that is prompting such coalition formation and opportunistic behavior on the part of various stakeholders, both within and outside government. Reflecting a change in the roles of both public and private sectors in India, these coalitions are formed by groups of individuals who have access to a set of key resources that include, but are not limited to, a strong set of (mostly informal, personal) social and political connections and financial capital. To illustrate, the farmers in this study were able to leverage their social and political networks in order to successfully take advantage of emerging development opportunities in Pune. The catalyst that converts a social network into a coalition is the ability of one or two key individuals like the leader of this particular farmer community in Pune, Satish Magar - to recognize or sometimes create an opportunity out of emerging circumstances and consequently bring together in a coalition other key persons who bring specific resources to the group. These individuals need not be central controlling figures of authority like a mayor or a prominent corporate leader. Although socially and politically well connected, Magar is not politically active himself and neither was he among the leading entrepreneurs in Pune until he successfully developed Magarpatta City. His success lies in the fact that he was able to leverage his personal connections to form several small alliances or coalitions that allowed him and his community to successfully develop their land.

I conducted the research for this article in 2008-09 in India. ${ }^{3}$ Primary data were collected through a series of semi-structured personal interviews: I used a set of questions to guide the interview process but respondents were free to direct the conversation towards their respective areas of expertise and knowledge. Drawing on Fainstein's methodology in The City Builders (2001), I used a reputational method to identify respondents, relying on them to point me to others who would be potentially valuable informants. In all, about 20 interviews were conducted. The length of the interviews ranged from 30 minutes to 2 hours. A few of the respondents were interviewed more than once. Several respondents requested anonymity and are therefore not identified directly in the text below. Those interviewed included the developers of Magarpatta City as well as key employees and associates of the development company, lawyers, bankers, architects, real estate developers, former and present government officials, academics, journalists and knowledgeable observers in Pune and Mumbai. Secondary data were collected from government reports, reports from consulting firms and newspaper archives.

\section{Building Magarpatta City}

Pune is the second largest city after Mumbai in the state of Maharashtra, with a population of around 5 million, located 163 kilometers or approximately 100 miles east

3 Some of the data were collected prior to the economic crisis and may not reflect recent changes. In general, however, Indian cities (especially the smaller ones) have witnessed a slowdown in the rates of urban development and returns that investors are earning on investments in real estate. There has also been a sharp reduction in international funds investing in urban development projects in Indian cities. 
of Mumbai. Pune has been a stronghold for manufacturing and is also a thriving center for higher education (Shaw, 1999). In the last couple of decades, the city has seen rapid urbanization that coincided with its emergence as a regional and national hub for information technology and biotechnology, while maintaining its strong connections to agriculture. However, despite the growing presence of multinational companies in the city, the majority of the businesses in Pune are still controlled by locals, most of the development that takes place is locally driven and funded, and connections between people, whether social or commercial, remain intensely personal. Another unusual aspect, at least with respect to urban development, that came to light during my interviews in Pune is the relative absence of the non-resident Indian or NRI. Several Indian cities, most notably Bangalore and Hyderabad have entire neighborhoods catering to NRIs who also play a large part in funding development in India. This is not yet the case in Pune where international involvement in urban development has been minimal.

Pune's rapid growth has been partly fueled by government incentives, especially for emerging sectors like information technology, biotechnology and related industries. The state government has created an incentive package for these sectors, offering them 'geobribes' (Roy, 2009) in the form of cheap land and tax incentives (such as waiver of stamp duties, interest and tax holidays and reduction of other fees like electricity and water payments) in return for locating in Pune (Government of Maharashtra, 2007). Pune's growth has also led to an increased demand for housing and office space that quickly outstripped what was available in the city. Officially, the Pune Municipal Corporation (PMC) is responsible for the urban planning and development of the city together with the state town-planning directorate. However, the PMC tends to take a more reactive approach to planning, acting more as a regulator than actively planning for city growth and development, focusing more on regulation of development and infrastructure development in the city on a case-by-case basis. In addition, most of the decision making and power in India is concentrated at higher levels in the governmental structure - in this case, in the hands of the state government. This has resulted in the ineffectual management of the city, partly because of a weak city government and continual state-level interference. Pune has thus grown incrementally with the need for housing and other services being organically met by local developers and residents.

Pune's farmers have been key players in the city's real estate development industry. They are also an extremely powerful community, financially and politically, as a consequence of their involvement in the sugar cooperatives. ${ }^{4}$ In addition to fostering a culture of cooperation and collaboration, the sugar cooperatives were also extremely influential politically (Chithelen, 1980/1981; Lalvani, 2008). Farmers in Pune are therefore no strangers to politics. While land acquisition and development is highly politicized in Pune, as in most Indian cities, what is unusual is the role that farmers play in the development process. They own a significant amount of land in and around Pune. They are also highly involved in politics at the local level. As a result, in Pune, the farmers, local politicians and the real estate lobby overlap to a large extent.

Located on the eastern periphery of Pune, Magarpatta City stands on 400 acres of erstwhile farmland that has been owned by the Magar farming community for over 300 years. ${ }^{5}$ The part of Pune that is home to Magarpatta City also houses a large industrial estate as well as several Information Technology (IT), Information Technology Enabled Services (ITES) and biotechnology companies. Consequently there was and continues to

4 A very successful cooperative movement, which began around the 1950s, controls sugarcane farming and the manufacture of sugar in Maharashtra. It was also very closely connected to local, regional and state-level politics. At one time, the leaders of the sugar cooperatives influenced the state government very strongly. This led to serious issues of corruption and power grabbing. While the cooperatives are still in operation, their hold over state politics is somewhat diminished. For more, see Chithelen (1985) and Lalvani (2008).

5 'Magar' is the name of the clan that owns most of the land in the area, while 'patta' means land strip. The name 'Magarpatta' therefore means 'the strip of land owned by the Magars'. 
be a great demand for housing space as well as commercial and retail establishments in the area. The farmers in the region were worried by the prospect of losing both their homes and livelihood if the area were to be developed as part of the city. Small farmers in the area had already begun to sell off their land. The Magar community knew that it would only be a matter of time before developers began to approach them to buy their property. Collectively, the community owned more than 400 acres of land. Taking advantage of the existing demand in the area, the farmers decided to pool their land and develop it themselves instead of selling it to another developer.

Magarpatta City owes its success largely to three key factors: the favorable economic climate in Pune at the time, the entrepreneurial nature of the Magar community, and of course, the coalitions that one of the farmers - Satish Magar was able to mobilize, by leveraging his social networks. Satish Magar is not an ordinary farmer. He comes from a very influential local family that is extremely well connected socially and politically. His grandfather was mayor of Pune. His uncle was a Member of the Legislative Assembly (MLA) in the Maharashtra state government and also later a Member of Parliament and highly influential, especially in state politics (Dalal, 2008). As politicians, both his grandfather and uncle had very close ties with the Congress Party, which happened to be in power in the state government in the 1990s, when Magarpatta City was being conceived. His father was an engineer and ran his own civil construction firm. Satish Magar was therefore familiar with both politics and project development. Moreover, he and his family were the largest landholders in the Magar community. Of the 400 acres that collectively belonged to the Magar farming community, Satish Magar and his family owned about 150 acres. All of this added to the influence that he had on the decision-making process within the farmer community.

Satish Magar and his social and political connections proved to be invaluable in the development of Magarpatta City. He leveraged his influence and kinship ties with the farmer community to encourage them to participate in the project. He also tapped into his vast personal social network to request advice and assistance from experts in a variety of fields as consultants to the project. Essentially two broad coalitions were formed, with Magar at the center of each. The first was an alliance that he formed with the farmer families in order to create the parcel of land on which the development was to take place. The second was actually a series of smaller alliances with specific individuals that came together as the board of directors of the company and in the form of various consultants to the project consisting of experts from different fields including IT, education, finance, and planning and design.

As a result of national economic liberalization policies started in the early 1990s, several multinational companies were looking for a foothold in the Indian market. They found Pune with its proximity to Mumbai and ready pool of highly skilled labor an attractive location. Demand for residential and office space soared, and the city government that planned for urban infrastructure and development in Pune was unable to keep up, providing the perfect opportunity to the private sector to fill the void. While several local developers jumped into the fray, Magarpatta City was one of the first projects to begin offering both office and residential space within the same walls. There continues to be a spate of large project development in and around Pune (Bari and Savitha, 2010; Chandrashekhar, 2010), most of which has been built by various coalitions between mostly local (Pune-based) real estate developers and city and statelevel politicians. What is unusual about Magarpatta City is that it was a very ambitious project born out of an alliance between the landowners, without any real estate developers being involved. More than most economic sectors in India, the real estate development sector depends hugely on personal connections, especially in government. Some of these are built up over several years by developers and architects. It is extremely difficult for newer players to enter the field.

The Magarpatta Township Development and Construction Company (MTDCC) was formed as a private limited company to oversee development and management of the 
project. Before forming the company, a variety of models were considered, including a cooperative approach. ${ }^{6}$ Prakash Deshmukh, the architect of Magarpatta City, explained to me that the driving idea behind the formation of a private limited company was to put a structure in place that functioned efficiently but was also democratic, thereby giving the landowners a say in the running of the business. He added that the formation of the company was made easier by the fact that all the farmers owned and farmed their own land. Each family got shares proportional to its landholding and was made an equity shareholder. ${ }^{7}$ The shares of the company may be held and traded among member families only, not publicly traded. The company is run by the managing director and the technical director in consultation with the board of directors, eight of whom come from the landholding families (Ganguli, 2008).

Drawing on a personal acquaintance, Satish Magar approached a prominent architect and designer from Mumbai, Hafeez Contractor, with a proposal to produce the initial master plan for the township. With the preliminary plan ready, Magar approached Sharad Pawar, the then Chief Minister of the state with whom he had close personal ties, for assistance in getting governmental permissions. ${ }^{8}$ This was a particularly challenging undertaking since permission for urban development on agricultural land in India is notoriously difficult to obtain. The recently retired Cabinet Secretary for the state of Maharashtra, Mr B.G. Deshmukh, another acquaintance, was one of the consultants on the project. He introduced Magar to the Secretary for Urban Planning in Maharashtra at that time, Mr D.T. Joseph, who took a personal interest in the project. These connections were vital to obtaining project approval and building permissions from the government. Magarpatta City was one of the first projects of its kind to be proposed in the state of Maharashtra. There were several legal and regulatory constraints in place at the time that would have made the construction of such a project challenging, such as the Urban Land Ceiling Regulation Act that had been put in place to prevent a few individuals or entities from controlling large plots of land. ${ }^{9}$ Navigating government bureaucracy and obtaining the requisite permissions would have been close to impossible for a group of farmers without these political connections.

Another major obstacle to the development of Magarpatta City was the lack of financing. As farmers, the Magars did not have significant capital to invest in the development of the project. However, they did have one big advantage: since they, as landowners, were themselves developing the land, they did not have any land acquisition costs nor any displacement or resettlement issues. Given the regulatory structure for lending to real estate companies in India at that time, it was difficult to get bank loans for development projects. ${ }^{10}$ In addition, bankers and financiers did not consider the project to be feasible - a group of farmers with no prior knowledge or experience in real estate development did not inspire confidence in lenders. Satish Magar was well acquainted with the retired Deputy General Manager (DGM) of one of the leading development

6 Deshmukh emphasized that the cooperative approach was rejected partly based on the experiences of the sugar cooperative movement in Maharashtra, but also because landholding sizes within the community varied immensely. A cooperative structure would have stressed equality rather than equity and might have dampened some of the enthusiasm and initiative that the families had. In addition, since landholding sizes ranged from one acre to 150 acres, giving equal importance to all landholders would have taken away the incentive the farmers had for pooling their land. See also Ganguli (2008).

7 Each share is equal to one square meter of land.

8 Pawar was then a very high-ranking leader in the Congress Party. He now heads his own political party: the Nationalist Congress Party (NCP). He comes from a small village near Pune and is extremely influential in the region. He has a very close relationship with the sugar cooperatives and the farmers in the area. His daughter and nephew continue to be prominent in regional politics in Pune. Magar's family knew him as a result of their political background.

9 Magarpatta City's proposal to pool land together would have been in violation of this act. The act has since been abolished.

10 Loans in India are typically granted for construction costs rather than land acquisition. 
finance institutions in India - the Housing Development Finance Corporation (HDFC). On the DGM's advice, Magar approached the managing director of HDFC, Deepak Parekh, and managed to obtain an initial loan of Rs 2 crore (approximately US $\$ 420,000^{11}$ ) to help them start construction (Dalal, 2008). ${ }^{12}$ Moreover, Deepak Parekh shared a personal rapport with Magar and provided valuable guidance on the actual construction and marketing process (ibid.). HDFC also entered into a preferential lender agreement with MTDCC whereby it offered lower rates of interest for retail home loans to those interested in buying property in Magarpatta City.

The actual planning and design process was essentially managed and controlled by the board of directors. The company promoted entrepreneurship among the farmers and encouraged it by providing special training to develop particular skill sets. The time it took to get the necessary clearances from the government was used for capacity building. At least one working member from each of the 120 families was trained so that he would be able to assist with the actual construction of the project. Some farmers were sent to various construction sites across India to study how other projects were being executed, while others were sent to learn construction management or other specific skills at local technical institutes. As a result, the company had its own team trained by the time it was ready to start construction. This had a dual purpose: not only did it cut down on the cost of construction since the work was being done in-house; it also helped erstwhile farmers to gradually transition into alternative occupations, ensuring that they were not unemployed when their land was put to non-agricultural uses.

The farmers themselves did most of the actual work from laying bricks and shifting soil with their farming equipment to managing the construction project. The first phase of construction involved the simultaneous building of villas, a few apartment blocks, some commercial space, plus part of the IT Park. The development targeted IT firms and their potential employees. The money that was generated by selling or leasing these developments funded further construction. Also, the company assured itself a constant revenue stream by not selling any of the commercial space in the IT Park but only leasing it. It also retained control over the maintenance of the entire project. The construction process began in 2000: the first residential buildings and the school were ready by 2003 and the first phase of office space followed in 2004. As of 2008, Magarpatta City is about $80 \%$ complete. A total of 7,500 apartments are planned, of which about $90 \%$ have already been sold. The total residential population, once development is complete, is anticipated to be around 100,000 people. The current residential population is 50,000 people and the working population is 6,500. Most of the people living in Magarpatta City (apart from the farmer families) are newer migrants to Pune who moved there to work in the IT or related industries. A large number of people living in Magarpatta City also work at companies located in the IT Park.

Post-development, most of the farmer families continue to stay on site and own either apartments or villas that they have bought with the money they made through the company. Moreover, some of them have succeeded in renting out some of their property, creating yet another source of income. The land also continues to be registered in their name, maintaining ownership and giving them a sense of security. Farmer families have also managed to move beyond agriculture and into other occupations. Several spin-off subsidiary businesses have emerged such as local companies providing cable TV and broadband internet, catering and food supply, laundry, landscaping and a local transport system. About $70 \%$ of the families are now under tax audits, earning a minimum of Rs 40 lakh (approximately US \$85,000) a year and paying a total of about Rs 10-12 crores in taxes as a community (Dalal, 2008).

11 US \$1 is approximately equal to Rs 48 at the present exchange rate.

12 Once the government approves plans, the financial institution loans money on a phase-by-phase basis, requiring the simultaneous development of a revenue stream and the completion of one phase of construction prior to loaning more money. 
Magarpatta City owes its success to the Magars' ability to leverage their social networks and kinship ties to first build an informal working coalition and convert that into a more formal arrangement in the form of the development company. It has been heralded as a huge success by the media and the government (Financial Express Bureau, 2004; Arun, 2006; Ganguli, 2008; Shah, 2009; Nair and Ahluwalia, 2010) - in part, this is due to sheer disbelief that something of this scale could be accomplished by a group of farmers. However, as with any large undertaking, it was not without its opponents, from both within the farming community and outside. ${ }^{13}$ Initially, the farmers were unwilling to pool their land because of the risks associated with the project and there were a few families that resisted and decided to go their own way. Local environmental groups and activists are not happy with the development either. They complain that Magarpatta City has begun a trend of using agricultural land in Pune to build large projects, raising food security threats. They also point to other areas around the city that were zoned for development in the proposed master plan but have not yet been developed. However, the opposition has not affected Magarpatta City much. The development is a success and the Magars are planning their next project, to be built a little outside Pune, along the same lines.

\section{Coalitions and urban development}

Power in Indian cities is fragmented. Unlike in the US, where a handful of powerful individuals control city development (Stone, 1989) (like Atlanta's mayors or the 'Vault' in Boston), no single group in Indian cities has enough power to control development or governance policy, leading to a need for collaboration and cooperation. City governments lack the power or the authority needed for taking decisions. Urban governance and development functions are spread across different government agencies. Power in Indian cities is distributed across different groups — ranging from the "petty bourgeoisie', including rich farmers, merchants and small property owners, across the 'new middle class', comprising those with advanced professional degrees and cultural capital occupying important positions in various institutions, to salaried workers in public and private sector enterprises (Fernandes and Heller, 2006). Each of these groups has access to a specific set of resources (such as financial capital, property, educational or technical expertise and governmental authority) that makes them valuable to the urban coalitions that are emerging to fill the gap created by the absence of a central font of power. Although a single group does not have the power or resources to influence change, different factions mobilize their resources through shared social and political networks that are leveraged to form urban coalitions, enabling them to share access to resources and achieve specific developmental and policy goals. What is important in the Indian example is the role that individual networks play. Interest groups are able to build on their personal networks to form specific goal-related coalitions. While regime theory frameworks are very useful in pointing us towards these issues by asking questions about the basis of power, forms of mobilization and power structures, they do not take us much further. Power structures in Pune are based on social relations: kinship networks, caste and community relations and personal friendships.

The coalitions in this case used these networks to effectively accomplish the development of Magarpatta City. Conditions created by the globalizing of the Indian

13 During fieldwork, it was very difficult to find anyone who would talk openly about any form of opposition to Magarpatta City. Despite several attempts, I was unable to talk to the farmer families that decided not to participate in the project. Extensive searches of newspaper archives also yielded little by way of critiques of the development. Despite there being clear evidence of opposition to the project, it has not been vocalized very prominently. Most respondents during interviews downplayed their concerns and requested that they remained anonymous, citing Sharad Pawar's involvement with the project as the reason. 
economy presented the Magar community with an unusual opportunity that they capitalized on by using their social and political networks. The Magar community and, more specifically, Satish Magar recognized the potential in developing the land themselves. They began by building on the mutual cooperation and trust from years of farming in an agricultural cooperative. They also used their kinship ties and social networks to control relations within the coalition - Satish ' $d a d a$ ', ${ }^{14}$ as he is fondly called, had been a prominent member of the community and emerged as the natural leader. He was able to create a coalition within the farmers that converted their social capital into a business relationship.

However, merely developing a successful internal coalition would have been pointless without the second external coalition that the development company formed with city and state-level actors like politicians, government bureaucrats and bankers. Had the farming community not forged these connections, this would have been yet another story of farmer displacement. Once again, these were networks that Satish Magar and his family had cultivated over three generations. He was able to draw on these networks to identify specific individuals who came to be part of the company's board of directors and act as independent consultants to the project. It is important to recognize here that most of the dealings (all of which were legal and above board) took place outside 'formal' governmental or business channels. This is due to the nature of the relationships and networks (informal, social, personal) that made the coalitions possible in the first place.

Successful coalition building therefore depends on three factors: access to political and financial resources, strong cohesive leadership and the ability to recognize and capitalize on opportunity. In the case of Magarpatta City, Satish Magar proved to be a capable leader by uniting the larger community in a common goal. He also provided the necessary political resources as well as the initial financial capital. The farmer families complemented this by providing their labor, in addition, of course, to the initial investment of land.

Neha Sami (nehasami@umich.edu), Department of Urban and Regional Planning, University of Michigan, 2000 Bonisteel Blvd, Ann Arbor, MI 48109, USA.

\section{References}

Aijaz, R. (2008) Form of urban local government in India. Journal of Asian and African Studies 43, 131-54.

Arun, T.K. (2006) Singur, look west at Magarpatta, the farmers' township. The Economic Times [WWW document]. URL http://articles.economictimes.indiatimes. com/2006-12-06/news/27429447_1_carproject-singur-agricultural-land (accessed 10 January 2012).

Bari, P. and R. Savitha (2010) Rush of integrated townships into Pune. The Economic Times [WWW document] URL http://articles.economictimes.indiatimes. com/2010-01-28/news/27606739_1_ township-status-pune-kolte-patil-developers (accessed 9 January 2012).

Baviskar, A. (2003) Between violence and desire: space, power, and identity in the making of metropolitan Delhi. International Social Science Journal 55.117, 89-98.

Benjamin, S. (2000) Governance, economic settings and poverty in Bangalore. Environment and Urbanization 12.1, 3556.

Benjamin, S. (2008) Occupancy urbanism: radicalizing politics and economy beyond policy and programs. International Journal of Urban and Regional Research 32.3, 719-29.

Chandrashekhar, V. (2010) As wealth rises in India, so do private towns. The Christian Science Monitor [WWW document]. URL http://www.csmonitor.com/World/AsiaSouth-Central/2010/0716/As-wealthrises-in-India-so-do-private-towns (accessed 9 January 2012).

14 In Marathi, the local language, 'dada' means 'elder brother'. 
Chatterjee, P. (2004) The politics of the governed. Columbia University Press, New York.

Chithelen, I. (1980/1981) Sugar cooperatives in Maharashtra. Social Scientist 9.5/6, 55-61.

Chithelen, I. (1985) Origins of co-operative sugar industry in Maharashtra. Economic and Political Weekly 20, 604-12.

Dahl, R.A. (2005) Who governs? Democracy and power in an American city. Yale University Press, New Haven, CT.

Dalal, S. (2008) Satish Magar narrates to MoneyLIFE how he created Magarpatta. MoneyLIFE [WWW document]. URL http://suchetadalal.com/ ?id=6cb2703a-038f-8ad1-492e8bc95d2d\& base $=$ sections $\& f \& t=$ Satish + Magar + narrates+to+MoneyLIFE+how+he+ created+Magarpatta+ (accessed 9 January 2012).

Dupont, V. (2007) Conflicting stakes and governance in the peripheries of large Indian metropolises - an introduction. Cities 24.2, 89-94.

Fainstein, S. (1995) Politics, economics, and planning: why urban regimes matter.

Planning Theory, 14, 34-41.

Fainstein, S. (2001) The city builders: property development in New York and London, 1980-2000. University Press of Kansas, Lawrence, KA.

Fernandes, L. and P. Heller (2006) Hegemonic aspirations. Critical Asian Studies 38.4, 495-522.

Financial Express Bureau (2004) Magarpatta: a dream town worth emulating. The Financial Express, Pune [WWW document]. URL http://www. financialexpress.com/news/magarpattaa-dream-town-worth-emulating/113825/ (accessed 9 January 2012).

Flyvberg, B. (2002) Bringing power to planning research: one researcher's praxis story. Journal of Planning Education and Research 21.4, 353-66.

Ganguli, R. (2008) The Magarpatta model for land acquisition. InfoChange News and Features [WWW document]. URL http:// infochangeindia.org/agenda/battles-overland/the-magarpatta-model-for-landacquisition.html (accessed 9 January 2012).

Ghertner, D.A. (2011) Gentrifying the state, gentrifying participation: elite governance programs in Delhi. International Journal of Urban and Regional Research 35.3, 50432.
Government of Maharashtra (2007) Package scheme of incentives. Industries, Energy and Labour Department of the Government of Maharashtra, Mantralaya, Mumbai.

Gupta, A. (1989) The political economy of post-independence India: a review article. The Journal of Asian Studies 48.4, 787-97.

Hansen, T.B. (2001) Wages of violence: naming and identity in postcolonial Bombay. Princeton University Press, Princeton, NJ.

Heitzman, J. (2004) Network city: planning the information society in Bangalore. Oxford University Press, New York.

Jha, M.S. and V. Sinha (2007) India Inc decides to hold on to land bank. The Economic Times [WWW document]. URL http://articles.economictimes.indiatimes. com/2007-12-01/news/27669103_1_landbank-land-assets-joint-ventures (accessed 10 January 2012).

Kamath, L. (2006) Achieving global competitiveness and local poverty reduction? Examining the public-private partnering model of governance in Bangalore, India. PhD thesis, Department of Urban Planning and Policy Development, Rutgers University, New Brunswick, NJ.

Khilnani, S. (1999) The idea of India. Farrar Straus Giroux, New York.

Kirby, A. T. and Abu-Rass (1999) Employing the growth machine heuristic in a different political and economic context: the case of Israel. In A.E. Jonas and D. Wilson (eds.), The urban growth machine: critical perspectives two decades later, State University of New York Press, Albany, NY.

Kohli, A. (1986) The state and development in the third world. Princeton University Press, Princeton, NJ.

Kohli, A. (1987) The state and poverty in India: the politics of reform. Cambridge University Press, Cambridge.

Kohli, A. (1990) Democracy and discontent: India's growing crisis of governability. Cambridge University Press, Cambridge.

Kohli, A. (2004) State-directed development: political power and industrialization in the global periphery. Cambridge University Press, Cambridge.

Kulcsar, L.J. and T. Domokos (2005) The post-socialist growth machine: the case of 
Hungary. International Journal of Urban and Regional Research 29.3, 550-63.

Kundu, A. (2003) Urbanisation and urban governance: search for a perspective beyond neo-liberalism. Economic and Political Weekly 38.29, 19-25.

Lalvani, M. (2008) Sugar co-operatives in Maharashtra: a political economy perspective. Journal of Development Studies 44.10, 1474-505.

Lauria, M. (1999) Reconstructing urban regime theory: regulation theory and institutional arrangements. In A.E. Jonas and D. Wilson (eds.), The urban growth machine: critical perspectives two decades later, State University of New York Press, Albany, NY.

Logan, J.R. (1976) Logan on Molotch and Molotch on Logan: notes on the growth machine-toward a comparative political economy of place. The American Journal of Sociology 82.2, 349-52.

Logan, J.R. and H.L. Molotch (1987) Urban fortunes: the political economy of place. University of California Press, Berkeley, CA.

Logan, J.R., R.B. Whaley and K. Crowder (1999) The character and consequences of growth regimes: an assessment of twenty years of research. In A.E. Jonas and D. Wilson (eds.), The urban growth machine: critical perspectives two decades later, State University of New York Press, Albany, NY.

Molotch, H. (1976) The city as a growth machine: toward a political economy of place. The American Journal of Sociology 82.2, 309-32.

Nair, J. (2005) The promise of the metropolis: Bangalore's twentieth century. Oxford University Press, New Delhi.

Nair, R. and I.J. Ahluwalia (2010) Magarpatta: building a city with rural-urban partnership. The Indian Express [WWW document]. URL http://www.indianexpress. com/news/magarpatta-building-a-city-withruralurban-partnership/623701/ (accessed 9 January 2012).

PTI (Press Trust of India) (2009) Mumbai will become truly global city: PM. DNA [WWW document]. URL http://www. dnaindia.com/mumbai/report_mumbaiwill-become-truly-global-city-pm 1247391 (accessed 10 January 2012).

Roy, A. (2003) City requiem, Calcutta: gender and the politics of poverty.
University of Minnesota Press, Minneapolis, MN.

Roy, A. (2009) Why India cannot plan its cities: informality, insurgence and the idiom of urbanization. Planning Theory 8.1, 76-87.

Shah, N. (2009) Model town. Tehelka Magazine [WWW document]. URL http://www.tehelka.com/ story_main41.asp?filename $=\mathrm{Bu} 210209$ model_town.asp (accessed 9 January 2012).

Sharma, S.N. and L.M. Thomson (2010) India Inc all charged up to build new urban centres. The Economic Times [WWW document]. URL http:// articles.economictimes.indiatimes.com/ 2010-03-28/news/28448535_1_brandnew-cities-urban-centres-private-sector (accessed 10 January 2012).

Shatkin, G. (2008) The city and the bottom line: urban megaprojects and the privatization of planning in Southeast Asia. Environment and Planning A 40.2, 383-401.

Shaw, A. (1999) Emerging patterns of urban growth in India. Economic and Political Weekly 34, 969-78.

Shaw, A. (2007) Introduction. In A. Shaw (ed.), Indian cities in transition, Orient Longman, Chennai.

Sridharan, N. (2008) New forms of contestation and cooperation in Indian urban governance. In I.S.A. Baud and J. de Wit (eds.), New forms of urban governance in India: shifts, models, networks and governance, Sage, New Delhi.

Srinivas, S. (2001) Landscapes of urban memory: the sacred and the civic in India's high-tech city. University of Minnesota Press, Minneapolis, MN.

Stone, C.N. (1989) Regime politics: governing Atlanta, 1946-1988, University Press of Kansas, Lawrence.

Strom, E. (2007) In search of the growth coalition: American urban theories and the redevelopment of Berlin. In E. Strom and J. Mollenkopf (eds.), The urban politics reader, Routledge, Oxford.

The Hindu (2010) City can be Manhattan of India. The Hindu Group [WWW document]. URL http://www.thehindu. com/news/cities/Hyderabad/article 436428.ece (accessed 9 January 2012).

Times News Network (2006) Centre to help make Pune a global city. The Times of 
India [WWW document]. URL http:// articles.timesofindia.indiatimes.com/ 2006-12-03/pune/27786934_1_jnnurmprojects-global-city-commonwealth-youthgames (accessed 9 January 2012).

United Nations Population Fund (2007) State of the world population 2007. United Nations Population Fund [WWW document]. URL http://www.unfpa.org/ swp/2007/english/introduction.html (accessed 9 January 2012).

Weinstein, L. (2008) Mumbai's development mafias: globalization, organized crime and land development. International Journal of Urban and Regional Research 32.1, 22-39.

Weinstein, L. (2009) Redeveloping Dharavi: toward a political economy of slums and slum redevelopment in globalizing Mumbai. PhD thesis, Department of Sociology, University of Chicago.

Wood, A.M. (2004) Domesticating urban theory? US concepts, British cities and the limits of cross-national applications. Urban Studies 41.11, 2103-18.

Yang, Y.-R. and C.-H. Chang (2007) An urban regeneration regime in China: a case study of urban redevelopment in Shanghai's Taipingqiao area. Urban Studies 44.9, 1809-26.

Zhang, T. (2002) Urban development and a socialist pro-growth coalition in Shanghai. Urban Affairs Review 37.4, 475-99.

\section{Résumé}

Dans une Inde toujours plus mondialisée, une communauté agricole de Pune (Maharashtra) confrontée à la perte de terres cultivées au profit de l'urbanisation a mis au point une solution originale. Réunissant leurs terres, les agriculteurs ont mobilisé leurs réseaux sociaux et politiques pour tirer parti du nouveau climat économique de Pune, créant une commune plurifonctionnelle sur les 160 hectares de leurs terres arables. Ils ont formé des alliances avec d'autres parties prenantes, à la fois au sein de la communauté agricole et aux niveaux de la ville et de l'État. Cette étude de cas souligne l'importance des coalitions ponctuelles dans les structures de pouvoir et les politiques des processus urbains en Inde. Dans les villes indiennes, ces coalitions sont nées d'une vacance du pouvoir politique et des responsables face à l'évolution des centres d'intérêt et des priorités des gouvernements national et régionaux, ainsi que des insuffisances croissantes dans la fourniture des services urbains. 